University of Nebraska - Lincoln

DigitalCommons@University of Nebraska - Lincoln

Faculty Publications, Department of Psychology

Psychology, Department of

8-2018

\title{
The Effect of MAOA and Stress Sensitivity on Crime and Delinquency: A Replication Study
}

Christa C. Christ

Hamilton College and the University of Nebraska-Lincoln, cchrist@uscupstate.edu

Joseph A. Schwartz

University of Nebraska Omaha, jaschwartz@unomaha.edu

Scott F. Stoltenberg

University of Nebraska-Lincoln, sstoltenberg2@unl.edu

Jonathan R. Brauer

Indiana University, jrbrauer@indiana.edu

Jukka Savolainen

University of Michigan-Ann Arbor, jsavolai@umich.edu

Follow this and additional works at: https://digitalcommons.unl.edu/psychfacpub

Part of the Criminology Commons, Genetics Commons, and the Psychology Commons

Christ, Christa C.; Schwartz, Joseph A.; Stoltenberg, Scott F.; Brauer, Jonathan R.; and Savolainen, Jukka, "The Effect of MAOA and Stress Sensitivity on Crime and Delinquency: A Replication Study" (2018). Faculty Publications, Department of Psychology. 947.

https://digitalcommons.unl.edu/psychfacpub/947

This Article is brought to you for free and open access by the Psychology, Department of at DigitalCommons@University of Nebraska - Lincoln. It has been accepted for inclusion in Faculty Publications, Department of Psychology by an authorized administrator of DigitalCommons@University of Nebraska - Lincoln. 
Published in Journal of Contemporary Criminal Justice 34:3 (August 2018), pp. 336-353;

doi: $10.1177 / 1043986218770001$

Copyright (C 2018 Christa C. Christ, Joseph A. Schwartz, Scott F. Stoltenberg, Jonathan R. Brauer, and Jukka Savolainen

Published online May 8, 2018.

Supplemental material follows the references.

\title{
The Effect of MAOA and Stress Sensitivity on Crime and Delinquency: A Replication Study
}

\author{
Christa C. Christ, ${ }^{1,2}$ Joseph A. Schwartz, ${ }^{3}$ Scott F. Stoltenberg, ${ }^{2}$ \\ Jonathan R. Brauer, ${ }^{4}$ and Jukka Savolainen ${ }^{5}$ \\ 1. Hamilton College, Clinton, New York, USA \\ 2. University of Nebraska-Lincoln, Lincoln, Nebraska, USA \\ 3. University of Nebraska Omaha, Omaha, Nebraska, USA \\ 4. Indiana University, Bloomington, Indiana, USA \\ 5. University of Michigan, Ann Arbor, Michigan, USA \\ Corresponding author - Christa C. Christ, Department of Psychology, Hamilton College, Clinton, NY 13323, USA, \\ email cchrist@hamilton.edu
}

\begin{abstract}
Across several meta-analyses, $M A O A$-uVNTR genotype has been associated with an increased risk for antisocial behavior among males who experienced early life adversity. Subsequently, early life stress and genetic susceptibility may have long-term effects on stress sensitivity later in life. In support of this assumption, a recent study found evidence, in two independent samples, for a three-way interaction effect $(\mathrm{cG} \times \mathrm{E} \times \mathrm{E})$ such that proximate stress was found to moderate the interactive effect of $M A O A-\mathrm{uVNTR}$ and distal stress on crime and delinquency among males. In light of recent developments in $\mathrm{CG} \times \mathrm{E}$ research, we attempted to replicate these findings in an independent sample of university students. Our results failed to support any $\mathrm{cG} \times \mathrm{E}$ or $\mathrm{cG} \times \mathrm{E} \times \mathrm{E}$ effects reported in the original study. Implications of a failed replication and general concerns for future $\mathrm{cG} \times \mathrm{E}$ research are discussed.
\end{abstract}


Keywords: monoamine oxidase A gene, antisocial, distal stress, proximate stress, childhood maltreatment

\section{Introduction}

Candidate gene-by-environment $(\mathrm{cG} \times \mathrm{E})$ research has grown exponentially in recent years, with applications to a variety of social science topics. Concern for the integrity of this agenda has also increased due to low overall replicability of scientific literature more broadly (Baker, 2016), and cG $\times$ E findings specifically (Duncan \& Keller, 2011; Risch et al., 2009). A recent article provided recommendations to address the challenges of $\mathrm{cG} \times \mathrm{E}$ research in response to the issues brought forth by the National Institute on Alcohol Abuse and Alcoholism (Dick et al., 2015). We find these recommendations, subsequently discussed, to be a compelling means toward efficient progress in understanding the underlying genetic architecture of complex behavioral phenotypes, and we rely on them here to evaluate current $\mathrm{cG} \times \mathrm{E}$ research.

The purpose of $\mathrm{cG} \times \mathrm{E}$ research is to examine the potential contribution of specific genetic variants to an observable outcome (i.e., "phenotype") in the context of varying environmental factors. However, because the effect of any one genetic variant is likely to be extremely small (Chabris, Lee, Cesarini, Benjamin, \& Laibson, 2015; Kendler, 2013), large samples (e.g., $N>1,000$ ) are needed to secure sufficient power for detecting a main effect of a candidate gene and, therefore, even larger sample sizes would be needed to reliably detect cG $\times$ E effects (Heo \& Leon, 2010). With this in mind, independent replications of cG $\times \mathrm{E}$ findings prior to publication are recommended but also do not sufficiently address all the issues raised by Dick et al. (2015).

In addition to a lack of sufficient statistical power, two additional methodological concerns with $\mathrm{cG} \times \mathrm{E}$ research are noteworthy. First, genetic variants are often selected and modeled without a clear theoretical link to the phenotype of interest. In particular, studies targeting candidate genes of the "usual suspect" variety, such as MAOA, are inconsistent with the polygenic contribution to most complex traits (Dick et al., 2015). Second, there is considerable heterogeneity in the operationalization and measurement of environmental factors (Dick et al., 2015). The review of "stress" measurements in particular has been shown to be widely variable in terms of validity, severity, type, and time period, suggesting that replication of studies involving stress as an environmental moderator are essential (Monroe \& Reid, 2008; Uher \& McGuffin, 2010). Despite these limitations, the existing literature appears to provide strong a priori reasons to consider the $M A O A-\mathrm{uVNTR}$ genotype as a potential moderator of the association between exposure to stressful experiences and criminal behavior. The results of multiple meta-analyses support the finding that $M A O A$ $\mathrm{uVNTR}$ genotype moderates the association between environmental adversity and risk for antisocial behavior (Byrd \& Manuck, 2014; Ficks \& Waldman, 2014). Moreover, the MAOA$\mathrm{uVNTR}$ has a known effect on the rate of transcription of the MAOA gene (Sabol, $\mathrm{Hu}, \&$ Hamer, 1998).

Based on these findings, and in light of the methodological issues surrounding $\mathrm{cG} \times \mathrm{E}$ research, the present study aims to replicate the results from a recent article by Wells et al. 
(2017) focusing on the interactive effect of MAOA-uVNTR genotype and stress on delinquent behavior. The findings from Wells et al. (2017) found proximal life stress to be associated with increased risk for criminal behavior in males. Critically important for the present study, they found this association to be stronger among males who had experienced distal stress in early development and were carriers of the low-functioning variant $(M A O A-\mathrm{L})$. We selected this article for replication for two reasons. First, it is among the first to recognize that the effect of distal stress (e.g., childhood trauma exposure), previously shown to be moderated by MAOA-uVNTR genotype, should be considered alongside proximate stress as an additional moderator $(\mathrm{cG} \times \mathrm{E} \times \mathrm{E})$. This theoretical innovation is motivated by the observation that early life stress is associated with hypothalamic-pituitaryadrenal (HPA) axis (i.e., stress response system) dysregulation, which may render individuals who experience early life stress more susceptible to stressful situations later in life (Frodl \& O'Keane, 2013; Heim \& Nemeroff, 2001). Second, the publication of the Wells, Armstrong, Boisvert, Lewis, Gangitano, and Hughes-Stamm (2017) article represents an eventful moment in the field of criminology, as it is the first study examining a measured gene published in the journal Criminology, the flagship journal of the American Society of Criminology (ASC) and the highest-ranking journal in the field. The goal of the current study is to attempt to reproduce the $\mathrm{cG} \times \mathrm{E} \times \mathrm{E}$ findings reported by Wells et al. (2017) using an alternative sample of Midwestern university students and similar self-report measurements of distal and proximate stress and delinquency collected by an independent research group to provide insight into the robustness of the reported effect.

\section{Method}

Specific details of the current sample and measurements are outlined in the following paragraphs. A direct comparison of methodological features of our study and of Wells et al. (2017) is provided in the Appendix.

\section{Participants}

Undergraduate students ( $N=765 ; 56.3 \%$ women; $80.1 \%$ Caucasian, $5.8 \%$ Hispanic, $5.5 \%$ Asian, 4\% multiracial, 3\% African American, 1.6\% other; age $M=19.53$ [ $S D=2.36$ ] years) attending a Midwestern University were recruited from either the Psychology Department's subject pool via online recruitment or the University's Criminal Justice Department via email recruitment. The 60-min study was approved by the institution's institutional review board (IRB) and following participant's consent included the completion of several questionnaires and donation of a saliva sample using an Oragene-DISCOVER (OGR-500) self-collection kit (DNA Genotek, Inc., Ottawa, Ontario, Canada) for genotyping purposes. Students from the Psychology Department were granted two course credits for their participation, while Criminal Justice students were paid US\$20. 


\section{Measures}

Distal stress

The Childhood Trauma Questionnaire (CTQ) used in this study is a short form of the original 70-item assessment of child abuse and neglect (Bernstein \& Fink, 1998). The questionnaire is a 25-item measure composed of five subscales: physical (e.g., "People in my family hit me so hard that it left me with bruises or marks"), sexual (e.g., "Someone tried to touch me in a sexual way or tried to make me touch them"), and emotional abuse (e.g., "I thought that my parents wished I had never been born"), as well as physical (e.g., "I had to wear dirty clothes"), and emotional neglect (e.g., "I felt loved" - reverse scored) when growing up. Items are measured on a 5-point scale (from 1, "Never True," to 5, "Very Often True"). To replicate Wells et al. (2017) as closely as possible, only the physical abuse (5 items) and verbal abuse ( 2 items within the emotional abuse subscale) subscale items were used. The variable was dichotomized to 0 ("Never or rarely experienced abuse"; 63.5\%) or 1 ("Experienced abuse at least sometimes"; $36.5 \%$ ).

\section{Proximate stress}

The Perceived Stress Scale is a 10-item self-report measure that asks about feelings and thoughts during the last month to gauge current levels of perceived stress (Cohen, Kamarck, \& Mermelstein, 1983). Example questions include "In the last month, how often have you been angered because of the things that were outside of your control?" and "In the last month, how often have you felt that you were on top of things" - reverse scored. Items are measured on a 5-point scale (from 1, "Never," to 5, "Very Often"). To replicate Wells et al. (2017) as closely as possible, items were dichotomized to 0 ("Never," "Almost Never," or "Sometimes") or 1 ("Fairly Often" or "Very Often") before calculating a total sum score, where higher scores indicate higher levels of perceived stress.

\section{Crime and delinquency}

The first measure of crime and delinquency consisted of six items asking participants whether or not they had engaged in a variety of criminal and delinquent behaviors in the past 12 months (e.g., "destroyed or vandalized property on purpose," "hit, slapped, punched, or hurt someone using physical force," "operated a car under the influence of alcohol"). A sum score of the dichotomous responses was used, with higher scores indicating participants engaged in a greater variety of criminal or delinquent behaviors. Due to significant levels of positive skew - and directly in line with Wells et al. (2017) - the resulting measure was natural log transformed prior to the estimation of the multivariate models.1 The second measure of crime and delinquency consisted of 26 items asking participants how often in their life they had engaged in a variety of criminal behaviors (e.g., "serious driving offense, such as driving while drunk, driving very recklessly, or speeding $20 \mathrm{MPH}$ over the posted speed limit," "purposefully damaged or destroyed things that did not belong to you," "threatened someone with a weapon"). An average score was used, which corresponds to the frequency of criminal or delinquent behaviors over a participant's lifetime, with higher scores corresponding to greater amounts of criminal or delinquent behavior. 


\section{Covariates}

Demographic variables of age and race were included as covariates. Age was mean centered and race was restricted to include only Caucasian (coded as 0 ) and Hispanic (coded as 1) participants. Table 1 provides the descriptive statistics of all measures for the current analytic sample and the previous study we are attempting to replicate.

\begin{tabular}{|c|c|c|c|c|c|}
\hline Variable & $M / \%$ & $S D$ & Range & $t / \chi^{2}$-test & $p$ value \\
\hline \multicolumn{6}{|l|}{ Current analytical sample } \\
\hline $\begin{array}{l}\text { Distal stress } \\
\text { Male (yes) } \\
\text { Female (yes) }\end{array}$ & $\begin{array}{l}33.4 \% \\
36.8 \% \\
28.6 \%\end{array}$ & & $0-1$ & 3.48 & .062 \\
\hline $\begin{array}{l}\text { Proximal stress } \\
\text { Male } \\
\text { Female }\end{array}$ & $\begin{array}{l}2.58 \\
2.35 \\
2.91\end{array}$ & $\begin{array}{l}2.23 \\
2.30 \\
2.30\end{array}$ & $0-9$ & 2.73 & .007 \\
\hline $\begin{array}{l}\text { Criminal behavior (past year) } \\
\text { Male } \\
\text { Female }\end{array}$ & $\begin{array}{l}1.25 \\
1.52 \\
0.87\end{array}$ & $\begin{array}{l}1.34 \\
1.42 \\
1.12\end{array}$ & $0-6$ & 5.39 & $<.001$ \\
\hline $\begin{array}{l}\text { Criminal behavior (lifetime) } \\
\text { Male } \\
\text { Female }\end{array}$ & $\begin{array}{l}0.41 \\
0.49 \\
0.29\end{array}$ & $\begin{array}{l}0.31 \\
0.33 \\
0.23\end{array}$ & $0-1.68$ & 7.07 & $<.001$ \\
\hline \multicolumn{6}{|l|}{ Wells et al. university sample } \\
\hline $\begin{array}{l}\text { Distal stress } \\
\text { Male (yes) } \\
\text { Female (yes) }\end{array}$ & $\begin{array}{l}42.2 \% \\
41.5 \% \\
43.4 \%\end{array}$ & & $0-1$ & 0.32 & $>.05$ \\
\hline $\begin{array}{l}\text { Proximal stress } \\
\text { Male } \\
\text { Female }\end{array}$ & $\begin{array}{l}2.46 \\
2.26 \\
2.85\end{array}$ & $\begin{array}{l}2.09 \\
1.99 \\
2.24\end{array}$ & $0-10$ & 2.24 & $<.05$ \\
\hline $\begin{array}{l}\text { Criminal behavior } \\
\text { Male } \\
\text { Female }\end{array}$ & $\begin{array}{l}0.17 \\
0.20 \\
0.13\end{array}$ & $\begin{array}{l}0.25 \\
0.28 \\
0.19\end{array}$ & $0-1.4$ & -2.16 & $<.05$ \\
\hline \multicolumn{6}{|l|}{ Wells et al. add health sample } \\
\hline $\begin{array}{l}\text { Distal stress } \\
\text { Male (yes) } \\
\text { Female (yes) }\end{array}$ & $\begin{array}{l}28.8 \% \\
28.9 \% \\
28.6 \%\end{array}$ & & $0-1$ & 0.11 & $>.05$ \\
\hline $\begin{array}{l}\text { Proximal stress } \\
\text { Male } \\
\text { Female }\end{array}$ & $\begin{array}{l}0.60 \\
0.59 \\
0.62\end{array}$ & $\begin{array}{l}1.04 \\
1.10 \\
0.93\end{array}$ & $0-8$ & -0.49 & $>.05$ \\
\hline $\begin{array}{l}\text { Criminal behavior (lifetime) } \\
\text { Male } \\
\text { Female }\end{array}$ & $\begin{array}{l}0.06 \\
0.08 \\
0.02\end{array}$ & $\begin{array}{l}0.14 \\
0.17 \\
0.06\end{array}$ & $0-1.4$ & 7.9 & $<.001$ \\
\hline
\end{tabular}

Note: $t$ values and chi-square values significant at the $p<.05$ level are presented in boldface.

\section{Genotyping}

DNA was extracted from saliva following the DNA Genotek OGR-500 Kit ethanol precipitation protocol with prepIT-L2P reagent (DNA Genotek, Inc., Ottawa, Ontario, Canada). $M A O A-\mathrm{uVNTR}$ was amplified using polymerase chain reaction (PCR) forward and reverse primers: 5'-TGCTCCAGAAACATGAGCAC-3' and 5'-TAGAC TTGGGGATCCGACTG-3'. 
The PCRs were performed in $25 \mu \mathrm{L}$ reactions containing $20 \mathrm{ng}$ of DNA, $1 \times$ GoTaq Master Mix (Promega, Madison, Wisconsin, USA), $10 \mu \mathrm{M}$ of each primer, and $10 \%$ dimethyl sulfoxide (DMSO). The PCR amplification conditions consisted of $5 \mathrm{~min}$ initial denaturation at $95^{\circ} \mathrm{C}$, followed by 35 cycles of $95^{\circ} \mathrm{C}$ for $30 \mathrm{~s}, 55^{\circ} \mathrm{C}$ for $30 \mathrm{~s}$, and $72^{\circ} \mathrm{C}$ for $40 \mathrm{~s}$ before a final elongation at $72^{\circ} \mathrm{C}$ for $10 \mathrm{~min}$. A secondary set of primers were used to genotype samples unable to be called by the first set of primers and for the discrepancy test. The secondary set of primers (10 $\mu \mathrm{M}$ of each primer), 5'-ACAGCCTGACCGTGGAGAAG-3' and 5'-AGGCTTACCTC GCAGGCAAG-3', were combined with 20 ng of DNA and 1× GoTaq Master Mix (Promega, Madison, Wisconsin, USA) in a final volume of $25 \mu \mathrm{L}$. The PCR amplification conditions consisted of $10 \mathrm{~min}$ initial denaturation at $95^{\circ} \mathrm{C}$, followed by 35 cycles of $95^{\circ} \mathrm{C}$ for $1 \mathrm{~min}, 55^{\circ} \mathrm{C}$ for $1 \mathrm{~min}$, and $72^{\circ} \mathrm{C}$ for $2 \mathrm{~min}$ before a final elongation at $72^{\circ} \mathrm{C}$ for $10 \mathrm{~min}$. PCR product was separated by electrophoresis on a $3 \%$ agarose gel and visualized under ultraviolet (UV) light with SYBR Safe stain. Two trained researchers made genotyping calls independently. Any sample inconsistently scored by these researchers $(2.2 \%$ of the sample) was re-genotyped. The $2 \mathrm{R}, 3 \mathrm{R}$, and $5 \mathrm{R}$ alleles were classified as low-activity alleles (MAOA-L) and the $3.5 \mathrm{R}$ and $4 \mathrm{R}$ were classified as high-activity alleles $(M A O A-\mathrm{H})$. Ten percent of samples were re-genotyped to test genotyping accuracy using the second primer set. No discrepancies were observed in the genotyping calls. The call rate for MAOA-uVNTR was $98.6 \%$. Following Wells et al. (2017), females carrying a heterozygous $(M A O A-\mathrm{H} / \mathrm{L})$ genotype were excluded from the analyses $(n=205)$. Table 2 provides $M A O A-\mathrm{uVNTR}$ allele distributions for the analytic sample.

\begin{tabular}{|c|c|c|c|c|c|c|}
\hline \multirow[b]{2}{*}{ Variable } & \multicolumn{3}{|c|}{$M A O A-\mathrm{L}$} & \multicolumn{3}{|c|}{$M A O A-\mathrm{H}$} \\
\hline & $3 R$ & $5 \mathrm{R}$ & $3 R / 5 R$ & $3.5 \mathrm{R}$ & $4 \mathrm{R}$ & $3.5 / 4 \mathrm{R}$ \\
\hline \multicolumn{7}{|l|}{ Male } \\
\hline Distal stress & 40 & 0 & - & 0 & 64 & - \\
\hline No distal stress & 66 & 3 & - & 1 & 109 & - \\
\hline Proximal stress, $M(S D)$ & \multicolumn{3}{|c|}{$2.38(2.12)$} & \multicolumn{3}{|c|}{$2.33(2.18)$} \\
\hline \multicolumn{7}{|l|}{ Female } \\
\hline Distal stress & 17 & 0 & 0 & 1 & 37 & 1 \\
\hline No distal stress & 25 & 0 & 5 & 2 & 102 & 6 \\
\hline Proximal stress, $M(S D)$ & \multicolumn{3}{|c|}{$2.38(1.75)$} & \multicolumn{3}{|c|}{$3.07(2.42)$} \\
\hline
\end{tabular}

Note: Males with MAOA-L reporting no proximal stress ( $n=24,22.02 \%)$; females with $M A O A$-L reporting no proximal stress $(n=7,14.89 \%)$; males with $M A O A-\mathrm{H}$ reporting no proximal stress $(n=45,25.86 \%)$; females with $M A O A-\mathrm{H}$ reporting no proximal stress $(n=23,15.44 \%)$. No significant $M A O A$ proximal stress $(r=-.06$, $p=.177)$ or $M A O A$ distal stress $(r=.05, p=.314)$ correlations detected. $M A O A-\mathrm{L}=$ low-functioning $M A O A$; $M A O A-\mathrm{H}=$ high-functioning $M A O A$.

\section{Statistical Analyses}

The analytic strategy was to follow the decisions reported by Wells et al. (2017) as closely as possible. First, bivariate correlations were estimated to examine the association between the $M A O A-\mathrm{uVNTR}$ genotype and the proximal and distal stress measures. These correlations reflect gene-environment correlations (rGEs) or the extent to which $M A O A$-uVNTR 
genotype is directly implicated in selection-based processes that increase the likelihood of experiencing distal or proximal stress. The next step of the analysis involved the estimation of Tobit regression models that examine potential multivariate associations involving proximal stress, distal stress, $M A O A-\mathrm{uVNTR}$ genotype, and delinquency. ${ }^{2}$ For the baseline Tobit model, the annual delinquency measure was regressed on the demographic covariates (i.e., participant age and race) along with the distal and proximal stress measures. In addition, a multiplicative interaction term between the distal and proximal stress measures was also included in the baseline model. For the full Tobit model, the $M A O A-\mathrm{uVNTR}$ genotype was included in the model along with two $\mathrm{cG} \times \mathrm{E}$ interaction terms: MAOA distal stress and $M A O A$ proximal stress. Finally, the full Tobit model also included a three-way interaction: $M A O A$ proximal stress $\times$ distal stress $(\mathrm{cG} \times \mathrm{E} \times \mathrm{E})$. The third step of the analysis involved the estimation of negative binomial regression models with the annual delinquency sum score (instead of Tobit regression with the log-transformed annual delinquency measure). As with the previous Tobit models, both a baseline and full model were estimated. The fourth and final step in the analysis involved the estimation of additional negative binomial regression models that were identical to the previous set except the annual delinquency outcome measure was replaced with the lifetime delinquency measure. Conforming to Wells et al. (2017), all of the regression models were estimated separately for the male and female subsamples.

\section{Results}

The first step of the analysis involved the calculation of bivariate correlations between $M A O A-\mathrm{uVNTR}$ genotype and the stress measures to test for the presence of $r \mathrm{GEs}$. The resulting correlations revealed nonsignificant correlations between $M A O A-\mathrm{uVNTR}$ genotype and distal stress $(r=.05, p=.313)$, as well as MAOA-uVNTR genotype and proximal stress $(r=-.06, p=.177)$. Similar to the findings reported by Wells et al. (2017), these findings fail to indicate the presence of an $r$ GE between $M A O A$-uVNTR genotype and stress measures examined in the current study (see Supplementary Table 1).

The next step was to estimate a series of Tobit regression models. The results are presented in Table 3, with the results for the male subsample in the first set and the results for the female subsample in the second set of columns. Model 1 is a baseline model that excludes the $M A O A-\mathrm{uVNTR}$ genotype measure and all of the accompanying interactions. As can be seen in Table 3, distal stress was marginally significantly associated with delinquency $(b=.27, p=.050)$ in the male subsample, indicating that males who had experienced distal stress were significantly more likely to engage in a greater variety of delinquency in the past year. Proximal stress was also significantly associated with delinquency within the male subsample $(b=.07, p=.019)$, but the interaction between distal and proximal stress $(b=-.01, p=.757)$ was not significantly associated with delinquency for males. For the female subsample, only proximal stress was significantly associated with delinquency $(b=$ $.08, p=.014)$, as the main effect of distal stress $(b=.34, p=.183)$ and the interaction term between distal and proximal stress $(b=-.05, p=.516)$ were statistically nonsignificant. 
Model 2 in Table 3 presents the results of the full model. As can be seen for the male subsample, distal stress $(b=.39, p=.024)$ and proximal stress $(b=.08, p=.034)$ were significantly associated with delinquency, but the interaction between both stress measures remained nonsignificant $(b=-.04, p=.453)$. In addition, the main effect of the MAOA-uVNTR genotype $(b=.04, p=.788)$, as well as the interactions between MAOA-uVNTR genotype and distal stress $(b=-.32, p=.227)$ and $M A O A-\mathrm{uVNTR}$ genotype and proximal stress $(b=-.03$, $p=.663$ ), were nonsignificant. Finally, the three-way interaction between the $M A O A-\mathrm{uVNTR}$ genotype, distal stress, and proximal stress was also nonsignificant $(b=.07, p=.405)$. A slightly different pattern emerged for the female subsample, wherein the main effect of proximal stress was significant $(b=.10, p=.002)$ along with the effect of the MAOA-uVNTR genotype $(b=.58, p=.047)$. In addition, the interaction between $M A O A-\mathrm{uVNTR}$ genotype and proximal stress was also significant $(b=-.30, p=.009)$, but the resulting negative coefficient was not in the expected direction, indicating that participants who experienced greater levels of proximal stress and were carriers of a low-activity $M A O A$-uVNTR allele engaged in significantly lower levels of delinquency. Finally, the three-way interaction between the MAOA-uVNTR genotype, distal stress, and proximal stress was nonsignificant $(b=.14, p=.426)$ in the female subsample.

In an effort to test the sensitivity of the findings from the Tobit models, the same models were estimated a second time using negative binomial regression, which is appropriate for overdispersed count outcomes and commonly used when examining outcome measures tapping delinquency or criminal behavior (Osgood, 2000). Because of these features, the untransformed annual delinquency measure (as opposed to the log-transformed measure that was used in the Tobit models) was included in the negative binomial models. The results of the negative binomial regression models are presented in Table 4 and reveal a pattern of results that largely overlap with the findings from the Tobit models. More specifically, in Model 1, both distal $(b=.36, p=.037)$ and proximal stress $(b=.11, p=.001)$ were significantly associated with delinquency in the male subsample, while only proximal stress $(b=.10, p=.040)$ was significantly associated with delinquency in the female subsample. The interaction between proximal and distal stress was nonsignificant in both the male $(b=-.03, p=.578)$ and female $(b=-.04, p=.682)$ subsamples. For Model 2 , only the effects of distal $(b=.56, p=.008)$ and proximal stress $(b=.12, p=.006)$ were significantly associated with delinquency for the male subsample. The two-way interactions involving $M A O A$-uVNTR genotype were nonsignificant, as was the three-way interaction involving the MAOA-uVNTR genotype and both stress measures $(b=.09, p=.306)$. For the female subsample, the main effect of proximal stress was significantly associated with delinquency $(b=.11, p=.023)$, as was the interaction between MAOA-uVNTR genotype and proximal stress $(b=-.40, p=.008)$, but once again the association was not in the expected direction. The three-way interaction between $M A O A-\mathrm{uVNTR}$ genotype, proximal stress, and distal stress was nonsignificant in the female subsample as well $(b=.20, p=.378)$.

We performed additional sensitivity checks in which the annual delinquency measure was replaced with a lifetime delinquency measure. This measure was coded to reflect overall delinquency frequency (as opposed to variety), resulting in a measure that matches the original study more closely with respect to the items and coding (Wells et al., 2017). The 
results from negative binomial regression models predicting the total count of lifetime delinquency are presented in Table 5 . The coefficients for distal $(b=.23, p=.075)$ and proximal stress ( $b=.05, p=.054)$ were not statistically significant in Model 1 for the male subsample, and only the coefficient for proximal stress $(b=.06, p=.039)$ was significantly associated with delinquency within the female subsample. The coefficient representing the multiplicative interaction between distal and proximal stress was nonsignificant in both subsamples. For Model 2 , the estimate for distal stress $(b=.34, p=.033)$ was significant in the male subsample, but none of the interaction terms were significant, including the three-way interaction between $M A O A-\mathrm{uVNTR}$ genotype, distal stress, and proximal stress $(b=.04, p=$ .599). A similar pattern emerged in the female subsample, with the exception that the coefficient for proximal stress $(b=.07, p=.029)$ was significant. However, none of the interaction terms, including the three-way interaction $(b=.21, p=.478)$, were statistically significant. 


\begin{tabular}{|c|c|c|c|c|c|c|c|c|c|c|c|c|}
\hline \multirow[b]{3}{*}{ Variable } & \multicolumn{6}{|c|}{ Males } & \multicolumn{6}{|c|}{ Females } \\
\hline & \multicolumn{3}{|c|}{ Model 1} & \multicolumn{3}{|c|}{ Model 2} & \multicolumn{3}{|c|}{ Model 1} & \multicolumn{3}{|c|}{ Model 2} \\
\hline & $b$ & $S E$ & $p$ & $b$ & $S E$ & $p$ & $b$ & $S E$ & $p$ & $b$ & $S E$ & $p$ \\
\hline Age & -.01 & .02 & .473 & -.01 & .02 & .503 & -.03 & .02 & .141 & -.04 & .02 & .121 \\
\hline Hispanic & -.31 & .15 & .045 & -.32 & .16 & .042 & -.27 & .36 & .455 & -.24 & .36 & .507 \\
\hline Distal stress & .27 & .14 & .050 & .39 & .17 & .024 & .34 & .26 & .183 & .38 & .33 & .246 \\
\hline Proximal stress & .07 & .03 & .019 & .08 & .04 & .034 & .08 & .03 & .014 & .10 & .03 & .002 \\
\hline Proximal stress $\times$ distal stress & -.01 & .04 & .757 & -.04 & .05 & .453 & -.04 & .06 & .516 & -.05 & .07 & .459 \\
\hline$M A O A-\mathrm{L}$ & & & & .04 & .17 & .788 & & & & .58 & .29 & .047 \\
\hline$M A O A-\mathrm{L} \times$ proximal stress & & & & -.03 & .06 & .663 & & & & -.30 & .11 & .009 \\
\hline$M A O A-\mathrm{L} \times$ distal stress & & & & -.32 & .27 & .227 & & & & -.25 & .54 & .644 \\
\hline$M A O A-\mathrm{L} \times$ proximal stress $\times$ distal stress & & & & .07 & .08 & .405 & & & & .14 & .18 & .426 \\
\hline$R^{2}$ & & .04 & & & .04 & & & .03 & & & .05 & \\
\hline$N$ & & 282 & & & 282 & & & 194 & & & 194 & \\
\hline
\end{tabular}

Note: Unstandardized coefficients presented with robust standard errors. Coefficients presented in boldface are significant at the $p<.05$. MAOA-L $=$ low-functioning $M A O A$. 
Table 4. Negative Binomial Regression Models Examining Delinquency in the Past Year by Sex

\begin{tabular}{|c|c|c|c|c|c|c|c|c|c|c|c|c|}
\hline \multirow[b]{3}{*}{ Variable } & \multicolumn{6}{|c|}{ Males } & \multicolumn{6}{|c|}{ Females } \\
\hline & \multicolumn{3}{|c|}{ Model 1} & \multicolumn{3}{|c|}{ Model 2} & \multicolumn{3}{|c|}{ Model 1} & \multicolumn{3}{|c|}{ Model 2} \\
\hline & $b$ & $S E$ & $p$ & $b$ & $S E$ & $p$ & $b$ & $S E$ & $p$ & $b$ & $S E$ & $p$ \\
\hline Age & -.02 & .02 & .394 & -.02 & .02 & .455 & -.07 & .04 & .091 & -.07 & .04 & .106 \\
\hline Hispanic & -.54 & .19 & .005 & -.55 & .20 & .006 & -.46 & .51 & .364 & -.42 & .51 & .405 \\
\hline Distal stress & .36 & .17 & .037 & .56 & .21 & .008 & .43 & .36 & .225 & .54 & .43 & .212 \\
\hline Proximal stress & .11 & .03 & .001 & .12 & .04 & .006 & .10 & .05 & .040 & .11 & .05 & .023 \\
\hline Proximal stress $\times$ distal stress & -.03 & .05 & .578 & -.06 & .06 & .335 & -.04 & .09 & .682 & -.06 & .09 & .548 \\
\hline$M A O A-\mathrm{L}$ & & & & .09 & .22 & .666 & & & & .53 & .40 & .184 \\
\hline$M A O A-\mathrm{L} \times$ proximal stress & & & & -.02 & .06 & .717 & & & & -.40 & .15 & .008 \\
\hline$M A O A-\mathrm{L} \times$ distal stress & & & & -.55 & .33 & .099 & & & & -.35 & .67 & .602 \\
\hline$M A O A-\mathrm{L} \times$ proximal stress $\times$ distal stress & & & & .09 & .09 & .306 & & & & .20 & .23 & .378 \\
\hline$R^{2}$ & & .04 & & & .04 & & & .02 & & & .04 & \\
\hline$N$ & & 282 & & & 282 & & & 194 & & & 194 & \\
\hline
\end{tabular}

Note: Unstandardized coefficients presented with robust standard errors. Coefficients presented in boldface are significant at the $p<.05$. MAOA-L $=$ low-functioning $M A O A$. 
Table 5. Negative Binomial Regression Models Examining Lifetime Delinquency by Sex

\begin{tabular}{|c|c|c|c|c|c|c|c|c|c|c|c|c|}
\hline \multirow[b]{3}{*}{ Variable } & \multicolumn{6}{|c|}{ Males } & \multicolumn{6}{|c|}{ Females } \\
\hline & \multicolumn{3}{|c|}{ Model 1} & \multicolumn{3}{|c|}{ Model 2} & \multicolumn{3}{|c|}{ Model 1} & \multicolumn{3}{|c|}{ Model 2} \\
\hline & $b$ & $S E$ & $p$ & $b$ & $S E$ & $p$ & $b$ & $S E$ & $p$ & $b$ & $S E$ & $p$ \\
\hline Age & .03 & .02 & .123 & .03 & .02 & .109 & .02 & .01 & .115 & .03 & .02 & .044 \\
\hline Hispanic & -.03 & .12 & .810 & -.03 & .12 & .754 & -.32 & .27 & .234 & -.27 & .24 & .269 \\
\hline Distal stress & .23 & .13 & .075 & .34 & .16 & .033 & .26 & .26 & .314 & .44 & .26 & .093 \\
\hline Proximal stress & .05 & .03 & .054 & .05 & .04 & .205 & .06 & .03 & .039 & .07 & .03 & .029 \\
\hline Proximal stress $\times$ distal stress & .00 & .04 & .931 & -.02 & .05 & .734 & -.03 & .06 & .648 & -.06 & .06 & .266 \\
\hline$M A O A-\mathrm{L}$ & & & & -.10 & .15 & .518 & & & & .11 & .30 & .707 \\
\hline$M A O A-\mathrm{L} \times$ proximal stress & & & & .01 & .05 & .807 & & & & -.13 & .10 & .167 \\
\hline$M A O A-\mathrm{L} \times$ distal stress & & & & -.32 & .24 & .184 & & & & -.64 & .88 & .459 \\
\hline$M A O A-\mathrm{L} \times$ proximal stress $\times$ distal stress & & & & .04 & .08 & .599 & & & & .21 & .30 & .478 \\
\hline$R^{2}$ & & .01 & & & .01 & & & .01 & & & .01 & \\
\hline$N$ & & 282 & & & 282 & & & 194 & & & 194 & \\
\hline
\end{tabular}

Note: Unstandardized coefficients presented with robust standard errors. Coefficients presented in boldface are significant at the $p<.05$. MAOA-L $=$ low-functioning $M A O A$. 


\section{Discussion}

Consistent with Wells et al. (2017), our study found evidence of an association between proximal stress and delinquency for both males and females as well as an association between distal stress and delinquency for males. However, contrary to the patterns reported in the original study, we did not observe any evidence of $\mathrm{cG} \times \mathrm{Es}$ or $\mathrm{cG} \times \mathrm{E} \times \mathrm{E}$ interactive effects in our research. Although we made every effort in our independent replication to retain similar sample, measures, and analytical approach, it is important to note that our study does not qualify as a direct replication. Specifically, our measures of stress were different. In our study, we used the CTQ, which is a valid and widely used measure (Bernstein \& Fink, 1998), to represent distal stress. However, the CTQ items included in our analyses ask individuals to report how often they experienced physical or verbal abuse "when growing up," as opposed to participants of the Wells et al. (2017) study, who were asked to report whether or not they had experienced abuse before 18 years old (physical and verbal abuse; Sample 1) and before sixth grade (physical abuse; Sample 2). Similarly, our measure of proximate stress was the Perceived Stress Scale (Cohen et al., 1983), which measured feelings of stress over the past month, as opposed to Wells et al. (2017), which measured proximate stress using two versions of the List of Threatening Experiences Questionnaire that asked participants to indicate if they had experienced specific stressful events during the past 12 months. Although our measures are very similar (see comparison of descriptive statistics in Table 1) and we were able to replicate the associations between stress and delinquency, the effect of stress on behavior and disease is likely influenced by the type of stress and the timing of the stressor (Dick et al., 2015). Finally, our measurement of delinquency was also somewhat different. Although both studies asked participants about their engagement in delinquent behaviors over the past year, there were some differences across specific items. For example, the scale used in our research did not ask about "using force to obtain sex or money." It is worth noting, however, that many of the items used in our research were quite similar to the scale used in the original study (e.g., "destroyed or vandalized property on purpose," "hit, slapped, punched, or hurt someone using physical force," "sold or purchased drugs"), and the frequency of reported delinquent behaviors is similar across the samples (see Table 1). Still, we cannot rule out the possibility that differences in measurement prevented us from observing evidence of the $\mathrm{cG} \times \mathrm{E} \times \mathrm{E}$ reported in the original study.

It is also possible that our sample size was not large enough to detect a significant $\mathrm{cG} \times$ $\mathrm{E} \times \mathrm{E}$ effect. Wells et al. (2017) found a significant $\mathrm{cG} \times \mathrm{E} \times \mathrm{E}$ effect in two separate samples (Sample 1 male $n=173$; Sample 2 male $n=808$ ), but we were unable to replicate their findings in our sample (male $n=282$ ) even though it was larger than their undergraduate sample (Sample 1). Recent recommendations have suggested that gene main effects are likely to be small and suggest that even moderately sized samples $(N<1,000)$ are likely to be underpowered (Dick et al., 2015). In light of this, a significant number of $\mathrm{cG} \times \mathrm{E}$ studies are likely to be seriously underpowered as such studies require four times larger samples than those estimating main effects. By extension, the required samples' size for estimating cG $\times$ $\mathrm{E} \times \mathrm{E}$ effects is fourfold of the sample needed for $\mathrm{CG} \times \mathrm{E}$ effects (Heo \& Leon, 2010). Furthermore, due to file drawer bias (i.e., the fact that statistically nonsignificant associations 
are less likely to be published; Duncan \& Keller, 2011), the true size of any cG $\times$ E effect is likely to be smaller than what the literature indicates. This state of affairs further underscores the need for adequately powered samples. Taken together, it is reasonable to assume that the size of the sample analyzed in the current study, in addition to the samples analyzed by Wells et al. (2017), are all underpowered and thus the $c G \times E \times E$ effect should be interpreted with caution. This conclusion is all the more compelling in view of the fact that the only statistically significant $\mathrm{cG} \times \mathrm{E}$ effect observed in the present study was in the opposite direction to what is typically reported in the literature.

There are additional reasons why the $\mathrm{cG} \times \mathrm{E} \times \mathrm{E}$ effect, in both the current study and Wells et al. (2017), should be interpreted with caution. First, models that examine $c G \times E$ effects and include confounding variables (e.g., race, age) as covariates should also include controls for interaction terms between these confounds and both gene and environment measures (Dick et al., 2015). Failing to account for potential interactions between the included covariates, the measured genotype, and the focal environmental influences may bias any observed $\mathrm{cG} \times \mathrm{E}$ (or $\mathrm{cG} \times \mathrm{E} \times \mathrm{E}$ ) effect (Keller, 2014). Second, $M A O A-\mathrm{uVNTR}$ genotype has been previously shown to correlate with maternal antisocial behavior, which subsequently is correlated with transmission of risk for antisocial behavior (Kim-Cohen et al., 2006). Therefore, limiting an examination of $r$ GEs to only the MAOA-uVNTR genotype and participants' stress may be insufficient to fully account for any potential $r$ GE. These issues are not unique to Wells et al.'s (2017) paper, rather they are pervasive in the cG $\times \mathrm{E}$ literature and have been discussed (along with their accompanying limitations) elsewhere (Dick et al., 2015; Duncan \& Keller, 2011).

Concerns with insufficient statistical power underscore the need for genome-wide association studies (GWAS) and the use of polygenic risk scores (PRS) over $\mathrm{CG} \times \mathrm{E}$ studies to investigate the genetic architecture of complex traits and behaviors (Belsky et al., 2016; Tielbeek et al., 2017). There are more and more examples in recent literature of GWAS studies using massive samples consisting of tens, even hundreds of thousands of individuals. Such designs provide the research community with exceptional statistical power to investigate potentially small contributions of hundreds of thousands of single nucleotide polymorphisms (SNPs) on the underlying etiological development of a given phenotype (Eichler et al., 2010; Finucane et al., 2015). Similarly, the use of a PRS allows researchers to examine the combined contribution of all examined SNPs on a given phenotype, typically weighted by their respective contribution, resulting in increased effect sizes and consequently, greater statistical power than what could have been accomplished by examining each SNP independently (Plomin, Haworth, \& Davis, 2009). In short, the rapid evolution of GWAS techniques and the proliferation of available genome-wide data offers a promising future for behavior genetic studies aimed at examining the extent to which measured genes are associated with complex traits.

As demonstrated by our research, an independent replication (i.e., data collected and analyzed by an independent research group) may yield different results compared to a replication performed by the research group that produced the primary set of findings. Although the reasons for the discrepant findings (e.g., sampling error, small sample size, and measurement specificity) between Wells et al. (2017) and our replication study cannot be determined, the results of this replication illustrate the overall fragility of $\mathrm{cG} \times \mathrm{E}$ effects. 
As such, our research echoes recent concerns regarding the ability to replicate $c G \times E$ findings and underscores the need to follow recommended guidelines for investigating $\mathrm{cG} \times \mathrm{E}$ interactions in an effort to advance scientific knowledge about the genetic architecture of complex behavioral phenotypes (Dick et al., 2015).

Declaration of Conflicting Interests - The authors declare no potential conflicts of interest with respect to the research, authorship, and/or publication of this article.

Funding - This study was supported by a research grant from Fund for Investing in the Research Enterprise (FIRE), University of Nebraska Omaha.

Author Biographies - Christa C. Christ is currently a visiting assistant professor of psychology at Hamilton College. Her research focus primarily involves examining the interactive effect of genetic variation and stressful vs. supportive environments on risky and social behaviors.

Joseph A. Schwartz is an assistant professor in the School of Criminology and Criminal Justice at University of Nebraska at Omaha. His research interests include life-course/developmental criminology, behavior genetics, biosocial criminology, and additional factors involved in the etiology of criminal behavior. His recent works appear in outlets spanning multiple disciplines including Criminology, Journal of Research in Crime \& Delinquency, Journal of Quantitative Criminology, Criminal Justice $\mathcal{E}$ Behavior, Journal of Youth \& Adolescence, Intelligence, Journal of Affective Disorders, Journal of Adolescent Health, and Developmental Psychology.

Scott F. Stoltenberg is an associate professor of psychology at the University of Nebraska-Lincoln. His research is primarily focused on better understanding the role of genetic variation in individual differences in health-risk and social-behaviors.

Jonathan R. Brauer is an assistant professor of Criminal Justice at Indiana University Bloomington. His research tests theories of deviant and criminal behavior and explores consequences of coercive and supportive social environments. You can find his published work in various interdisciplinary journals, including Criminology, Journal of Research on Adolescence, and Justice Quarterly.

Jukka Savolainen is a research professor at the Institute for Social Research, University of Michigan, where his primary responsibility is to serve as the director of the National Archive of Criminal Justice Data. Most of his research is focused on etiological investigations of crime, violence, and victimization. 
CHRIST ET AL., JOURNAL OF CONTEMPORARY CRIMINAL JUSTICE 34 (2018)

\begin{tabular}{|c|c|c|c|}
\hline \multicolumn{4}{|l|}{ Appendix } \\
\hline & $\begin{array}{l}\text { Current analytical sample } \\
\qquad(N=765)\end{array}$ & $\begin{array}{l}\text { Wells et al. university } \\
\text { sample } \\
(N=521)\end{array}$ & $\begin{array}{l}\text { Wells et al. add health } \\
\text { sample } \\
(N=2,611)\end{array}$ \\
\hline \multicolumn{4}{|l|}{ Population } \\
\hline Location & Midwestern University & Southern University & Nationally representative \\
\hline Age & $M=19.53(S D=2.36)$ years & $M=21.35(S D=2.96)$ years & $M=21.93(S D=1.69)$ years \\
\hline Gender & $56.3 \%$ Female & $50 \%$ Female & $37.4 \%$ Female \\
\hline Race & $\begin{array}{l}85.9 \% \text { Caucasian or } \\
\text { Hispanic }\end{array}$ & $\begin{array}{l}\text { 75.3\% Caucasian or } \\
\text { Hispanic }\end{array}$ & $\begin{array}{l}\text { 81.7\% Caucasian or } \\
\text { Hispanic }\end{array}$ \\
\hline \multicolumn{4}{|l|}{ Measurements } \\
\hline Distal stress & $\begin{array}{l}\text { CTQ-physical abuse (5 } \\
\text { items) and verbal abuse ( } 2 \\
\text { items) items. Variable was } \\
\text { dichotomized to } 0 \text { ("Never } \\
\text { or rarely experienced } \\
\text { abuse"; } 63.5 \% \text { ) and } 1 \\
\text { ("Experienced abuse at } \\
\text { least sometimes"; } 36.5 \% \text { ) }\end{array}$ & $\begin{array}{l}2 \text { items -"my parents } \\
\text { were verbally/physically } \\
\text { abusive." Variable was } \\
\text { dichotomized as } 0 \\
\text { ("Experienced neither } \\
\text { type"; } 57.8 \% \text { ) and } 1 \\
\text { ("Experienced at least one } \\
\text { type"; } 42.2 \%)\end{array}$ & $\begin{array}{l}1 \text { item-"By the time you } \\
\text { started the sixth grade, } \\
\text { how often had your par- } \\
\text { ents or other adult care- } \\
\text { givers slapped, hit, or } \\
\text { kicked you?" Variable was } \\
\text { dichotomized as } 0 \\
\text { ("Never"; } 71 \% \text { ) and } 1 \text { ("At } \\
\text { least once"; } 29 \% \text { ) }\end{array}$ \\
\hline Proximate stress & $\begin{array}{l}\text { PSS-feelings or thoughts } \\
\text { of perceived stress in the } \\
\text { past month. Items ( } 10 \\
\text { items) were dichotomized } \\
\text { to } 0 \text { ("Never," "Almost } \\
\text { Never," or "Sometimes") } \\
\text { or } 1 \text { ("Fairly Often" or } \\
\text { "Very Often") before cal- } \\
\text { culating a total sum score }\end{array}$ & $\begin{array}{l}\text { List of Threatening Experi- } \\
\text { ences Questionnaire } \\
\text { (LTE) - } 15 \text { items regarding } \\
\text { stressful experiences they } \\
\text { had in the past } 12 \text { months. } \\
\text { Sum score of (yes }=1, \text { no }=0 \text { ) } \\
\text { responses }\end{array}$ & $\begin{array}{l}\text { LTE }-14 \text { items similar to } \\
\text { university sample. Sum } \\
\text { score of }(\text { yes }=1, \text { no }=0 \text { ) } \\
\text { responses }\end{array}$ \\
\hline Delinquency & $\begin{array}{l}\text { 1. Natural log of the 6-item } \\
\text { sum score- whether or } \\
\text { not they had engaged in } \\
\text { a variety of criminal and } \\
\text { delinquent behaviors in } \\
\text { the past } 12 \text { months } \\
\text { 2. Average score of } 26 \\
\text { items-how often in } \\
\text { their life they had } \\
\text { engaged in a variety of } \\
\text { criminal behaviors }\end{array}$ & $\begin{array}{l}\text { Natural log of the } 15 \text {-item } \\
\text { average score-how often } \\
\text { engaged in a variety of } \\
\text { criminal/delinquent } \\
\text { behaviors }\end{array}$ & $\begin{array}{l}\text { Natural log of the } 14 \text {-item } \\
\text { average score-level of } \\
\text { involvement in various } \\
\text { nonviolent and violent } \\
\text { criminal activities }\end{array}$ \\
\hline
\end{tabular}

Note: $\mathrm{CTQ}=$ Childhood Trauma Questionnaire; PSS = Perceived Stress Scale 


\section{Notes}

1. As the untransformed measure contained zeros, a constant of 1 was added to all scores prior to transforming the measure. While Wells et al. (2017) do not indicate whether they added a constant to their delinquency measure prior to performing a log transformation, this practice is necessary for this procedure.

2. Models were estimated with the censoring point set to .10. As the censoring point used by Wells et al. (2017) was not reported, we chose a value that was just slightly larger than zero consistent with recommendations by Osgood, Finken, and McMorris (2002).

\section{References}

Baker, M. (2016). Is there a reproducibility crisis? Nature, 533, 452-454.

Belsky, D. W., Moffitt, T. E., Corcoran, D. L., Domingue, B., Harrington, H., Hogan, S., . . Caspi, A. (2016). The genetics of success: How single-nucleotide polymorphisms associated with educational attainment relate to life-course development. Psychological Science, 27, 957-972.

Bernstein, D. P., \& Fink, L. (1998). Childhood Trauma Questionnaire: A retrospective self-report. San Antonio, TX: The Psychological Corporation.

Byrd, A. L., \& Manuck, S. B. (2014). MAOA, childhood maltreatment, and antisocial behavior: Metaanalysis of a gene-environment interaction. Biological Psychiatry, 75, 9-17.

Chabris, C. F., Lee, J. J., Cesarini, D., Benjamin, D. J., \& Laibson, D. I. (2015). The fourth law of behavior genetics. Current Directions in Psychological Science, 24, 304-312.

Cohen, S., Kamarck, T., \& Mermelstein, R. (1983). A global measure of perceived stress. Journal of Health and Social Behavior, 24, 385-396.

Dick, D. M., Agrawal, A., Keller, M. C., Adkins, A., Aliev, F., Monroe, S., . . Sher, K. J. (2015). Candidate gene-environment interaction research: Reflections and recommendations. Perspectives on Psychological Science, 10, 37-59.

Duncan, L., \& Keller, M. C. (2011). A critical review of the first 10 years of candidate gene-by-environment interaction research in psychiatry. American Journal of Psychiatry, 168, 1041-1049.

Eichler, E. E., Flint, J., Gibson, G., Kong, A., Leal, S. M., Moore, J. H., \& Nadeau, J. H. (2010). Missing heritability and strategies for finding the underlying causes of complex disease. Nature Reviews Genetics, 11, 446-450.

Ficks, C. A., \& Waldman, I. D. (2014). Candidate genes for aggression and antisocial behavior: A meta-analysis of association studies of the 5HTTLPR and MAOA-uVNTR. Behavior Genetics, 44, 427-444.

Finucane, H. K., Bulik-Sullivan, B., Gusev, A., Trynka, G., Reshef, Y., Loh, P. R., . . Price, A. L. (2015). Partitioning heritability by functional annotation using genome-wide association summary statistics. Nature Genetics, 47, 1228-1235.

Frodl, T., \& O'Keane, V. (2013). How does the brain deal with cumulative stress? A review with focus on developmental stress, HPA axis function and hippocampal structure in humans. Neurobiology of Disease, 52, 24-37.

Heim, C., \& Nemeroff, C. B. (2001). The role of childhood trauma in the neurobiology of mood and anxiety disorders: Preclinical and clinical studies. Biological Psychiatry, 49, 1023-1039.

Heo, M., \& Leon, A. C. (2010). Sample sizes required to detect two-way and three-way interactions involving slope differences in mixed-effects linear models. Journal of Biopharmaceutical Statistics, 20, 787-802. 
Keller, M. C. (2014). Gene $\times$ environment interaction studies have not properly controlled for potential confounders: The problem and the (simple) solution. Biological Psychiatry, 75, 18-24.

Kendler, K. S. (2013). What psychiatric genetics has taught us about the nature of psychiatric illness and what is left to learn. Molecular Psychiatry, 18, 1058-1066.

Kim-Cohen, J., Caspi, A., Taylor, A., Williams, B., Newcombe, R., Craig, I. W., \& Moffitt, T. E. (2006). MAOA, maltreatment, and gene-environment interaction predicting children's mental health: New evidence and a meta-analysis. Molecular Psychiatry, 11, 903-913.

Monroe, S. M., \& Reid, M. W. (2008). Gene-environment interactions in depression research: Genetic polymorphisms and life-stress polyprocedures. Psychological Science, 10, 947-956.

Osgood, D. W. (2000). Poisson-based regression analysis of aggregate crime rates. Journal of Quantitative Criminology, 16, 21-43.

Osgood, D. W., Finken, L. L., \& McMorris, B. J. (2002). Analyzing multiple-item measures of crime and deviance II: Tobit regression analysis of transformed scores. Journal of Quantitative Criminology, 18, 319-347.

Plomin, R., Haworth, C. M. A., \& Davis, O. S. P. (2009). Common disorders are quantitative traits. Nature Reviews Genetics, 10, 872-878.

Risch, N., Herrell, R., Lehner, T., Liang, K. Y., Eaves, L., Hoh, J., ... Merikangas, K. (2009). Interaction between the serotonin transporter gene (5-HTTLPR), stressful life events, and risk of depression: A meta-analysis. Journal of the American Medical Association, 301, 2462-2471.

Sabol, S. Z., Hu, S., \& Hamer, D. (1998). A functional polymorphism in the monoamine oxidase A gene promoter. Human Genetics, 103, 273-279.

Tielbeek, J. J., Johansson, A., Polderman, T. J. C., Rautiainen, M. R., Jansen, P., Taylor, M., . . Posthuma, D. (2017). Genome-wide association studies of a broad spectrum of antisocial behavior. JAMA Psychiatry, 74, 1242-1250.

Uher, R., \& McGuffin, P. (2010). The moderation by the serotonin transporter gene of environmental adversity in the etiology of depression: 2009 update. Molecular Psychiatry, 15, 18-22.

Wells, J., Armstrong, T., Boisvert, D., Lewis, R., Gangitano, D., \& Hughes-Stamm, S. (2017). Stress, genes, and generalizability across gender: Effects of MAOA and stress sensitivity on crime and delinquency. Criminology, 55, 548-574. 
Supplementary Table S1. Bivariate Correlations between Proximal Stress and Delinquency by Sex

\begin{tabular}{|c|c|c|c|c|c|c|}
\hline \multirow[b]{2}{*}{ Group } & \multicolumn{3}{|c|}{ Males } & \multicolumn{3}{|c|}{ Females } \\
\hline & $r$ & $95 \% \mathrm{CI}$ & $n$ & $r$ & $95 \% \mathrm{CI}$ & $n$ \\
\hline \multicolumn{7}{|c|}{ Past Year Delinquency (Log-transformed) } \\
\hline$M A O A-\mathrm{L} /$ No Distal Stress & .18 & $-.06-.40$ & 69 & -.35 & $-.63-.01$ & 30 \\
\hline$M A O A-\mathrm{L} / \mathrm{Distal}$ Stress & .32 & $.01-.57$ & 40 & -.11 & $-.56-.39$ & 17 \\
\hline$M A O A-\mathrm{H} /$ No Distal Stress & .22 & $.04-.39$ & 110 & .28 & $.10-.44$ & 110 \\
\hline$M A O A-\mathrm{H} / \mathrm{Distal}$ Stress & .18 & $-.08-.41$ & 63 & .09 & $-.23-.40$ & 39 \\
\hline \multicolumn{7}{|c|}{ Past Year Delinquency (non-transformed) } \\
\hline$M A O A-\mathrm{L} /$ No Distal Stress & .24 & $.002-.45$ & 69 & -.35 & $-.63-.02$ & 30 \\
\hline$M A O A-\mathrm{L} / \mathrm{Distal}$ Stress & .37 & $.07-.61$ & 40 & -.10 & $-.55-.40$ & 17 \\
\hline$M A O A-\mathrm{H} /$ No Distal Stress & .29 & $.10-.45$ & 110 & .25 & $.06-.42$ & 110 \\
\hline$M A O A-\mathrm{H} /$ Distal Stress & .23 & $-.02-.45$ & 63 & .10 & $-.23-.40$ & 39 \\
\hline \multicolumn{7}{|c|}{ Lifetime Delinquency (non-transformed) } \\
\hline$M A O A-\mathrm{L} /$ No Distal Stress & .18 & $-.06-.40$ & 69 & -.02 & $-.37-.35$ & 30 \\
\hline$M A O A-\mathrm{L} / \mathrm{Distal}$ Stress & .25 & $-.07-.52$ & 40 & .07 & $-.42-.54$ & 17 \\
\hline$M A O A-\mathrm{H} /$ No Distal Stress & .14 & $-.05-.32$ & 110 & .21 & $.03-.39$ & 110 \\
\hline$M A O A-\mathrm{H} / \mathrm{Distal}$ Stress & .10 & $-.15-.34$ & 64 & -.04 & $-.35-.28$ & 39 \\
\hline
\end{tabular}

Note: Pearson correlation coefficients, 95\% confidence intervals, and sample sizes are displayed. Past year delinquency was log-transformed prior to estimating correlation coefficients. Coefficients presented in bold have an accompanying 95\% confidence interval that does not include zero. 